\title{
Type 1 cytokine response and treatment outcome of genital HPV lesions
}

\author{
G Stellato, P Nieminen, M Aho, T Lehtinen, M Lehtinen, J Paavonen
}

Objectives: To determine the role of type 1 cytokines as predictors of response to treatment of genital HPV lesions with laser ablation with or without adjuvant systemic interferon $\alpha 2 b$ (IFN- $\alpha$ ). Methods: Measurement of serum interleukin 2 (IL-2), IL-2 soluble receptor $\alpha$ (sIL-2 $\alpha$ ), interferon $\gamma$, and human papilloma virus (HPV) DNA in patients undergoing treatment of genital HPV lesions with carbon dioxide laser and systemic IFN- $\alpha$. A randomised, placebo controlled study of 92 cases with 6 months of follow up.

Results: High IL-2/sIL-2 $\alpha$ was associated with $60 \%$ to $70 \%$ protection against recurrences both in the IFN $-\alpha$ and placebo groups (OR $=0.4,90 \%$, CI $0 \cdot 1-2 \cdot 5$; OR $=0.3,90 \%$ CI $0.0-1 \cdot 8$, respectively). Diagnostic phase serum IL-2 predicted favourable outcome (OR $=0 \cdot 2,90 \% \mathrm{CI}$ $0 \cdot 0-1 \cdot 0$ ) in women with high load of HPV DNA or HPV16/18 DNA regardless of the adjuvant therapy.

Conclusions: Serum IL-2 determinations may identify women with good prognosis following laser ablation of genital HPV lesions.

(Genitourin Med 1997;73:387-390)

Keywords: human papilloma virus; cytokines

\section{Introduction}

Encouraged by successful use of human leucocyte interferon (interferon $\alpha$, IFN- $\alpha$ ) in the treatment of recurrent respiratory papillomatosis $^{1-3}$ several clinical trials have been conducted on the treatment of genital human papilloma virus (HPV) infections with interferons (for a review see Cirelli and Tyring ${ }^{4}$ ). Surgical excision with adjuvant systemic IFN- $\alpha$ gives better results than other treatment methods. Of nine studies reported ${ }^{4-7}$ only two $^{6} 7$ have failed to demonstrate beneficial effects.

Combination of IFN- $\alpha$ with other biological response modifiers, especially interleukin 2 (IL-2) has shown additive or synergistic effects in tumour immunotherapy..$^{8-10}$ On the other hand, increased expression of both IL-2 and soluble IL-2 receptor $\alpha$ (sIL-2 $\alpha$ ) contribute to allograft rejection, ${ }^{11}$ and have recently been associated with the extent of HPV positive cervical intraepithelial neoplasia (CIN). ${ }^{12}{ }^{13}$ These effects are largely mediated by the augmentation of cytotoxic T cell (CTL) response, normally stimulated by IL-2 producing $\mathrm{T}$ helper (Th1) cells. Interplay between CTLs and Th1 cells is presumed an important determinant of the clinical course of cervical HPV infection. The purpose of our study was to evaluate determinants of treatment outcome of genital HPV lesions with adjuvant IFN- $\alpha$ with special emphasis on the Th1 arm of cell mediated immunity as reflected by the serum cytokines interferon $\gamma$ (IFN- $\gamma$ ) and IL-2, and the sIL- $2 \alpha$.

\section{Materials and methods}

The study population, consisting of 100 women (mean age $24 \cdot 1$ years, range 16-57) referred to the gynaecological outpatient clinic, University Hospital, Helsinki, Finland, has been described in detail. ${ }^{5}$ All patients had histopathologically confirmed cervical HPV infection. Patients treated for genital warts during the last month were excluded (table 1).

Patient evaluation has been described in detail. ${ }^{5}$ Briefly, all women underwent standardised interview, and a gynaecological examination during which colposcopically directed cytological and histopathological as well as DNA samples were obtained from the cervix. A blood sample was drawn on the first visit.

All genital HPV lesions were surgically treated with carbon dioxide laser by the same gynaecologist (MA), as described. ${ }^{5}$ Adjuvant treatment with subcutaneously administered interferon $\alpha 2 b$ (Introna, Schering-Plough, Kenilworth, NJ, USA) ( 1.5 million units three times a week for 3 weeks, for a total 10 injections) or placebo was started immediately after laser surgery. The study was double blind, and the code was broken after the follow up period of 6 months was completed.

Follow up visits took place at 1, 3, and 6 months post-treatment. Clinical recurrence was defined as the reappearence of condylomata, an atypical transformation zone, or characteristic acetowhite lesions histopathologically consistent with flat condyloma.

Cervicovaginal cytological smears were taken by Ayres spatula and Cytobrush (Medscand Ab, Malmö, Sweden). Samples for the detection of HPV DNA were taken with a cotton tipped swab (ViraPap Specimen Collection Kit, Digene Diagnostics, Gaithersburg, MD, USA). Detection and typing of HPV DNA were performed by two dot blot hybridisation methods (ViraPap/Type, Digene) which detect 1-3 $\mu$ g of viral nucleic acid consistent with high load of HPV DNA. ${ }^{514-16}$ Histopathological criteria for the diagnosis of HPV infection on biopsy specimens have been described. ${ }^{14}$ 
Table 1 Characteristics of the study population

\begin{tabular}{lcc}
\hline Characteristics & $\begin{array}{c}\text { Interferon } \\
(n=50)\end{array}$ & $\begin{array}{c}\text { Placebo } \\
(n=50)\end{array}$ \\
\hline Age (years) (SD) & $22 \cdot 7(5 \cdot 7)$ & $25 \cdot 5(8 \cdot 9)$ \\
Age of first coitus (SD) & $17 \cdot 3(2 \cdot 6)$ & $17 \cdot 5(2 \cdot 4)$ \\
Mean number of lifetime partners & $9(1 \geqslant 150)$ & $7(1-25)$ \\
History of any STDs & $22(44 \%)$ & $31(62 \%)$ \\
History of any STDs† & $22(47 \%)$ & $29(62 \%)$ \\
History of genital warts & $15(30 \%)$ & $17(34 \%)$ \\
HPV DNA findings & $16(32 \%)$ & $11(22 \%)$ \\
HPV 6/11 & $8(16 \%)$ & $5(12 \%)$ \\
HPV 16/18 & $7(14 \%)$ & $11(22 \%)$ \\
HPV 31/33/35 & $4(8 \%)$ & $4(8 \%)$ \\
HPV multiple & $23(36 \%)$ & $19(28 \%)$ \\
negative & $7(16 \%)$ & $1(2 \%)$ \\
Cytokine status $\ddagger$ & $8(18 \%)$ & $10(21 \%)$ \\
Interferon $\gamma$ & $23(51 \%)$ & $27(57 \%)$ \\
Interleukin 2 (IL-2) & $6(13 \%)$ & $9(19 \%)$ \\
IL-2 receptor (sIL-2R $\alpha \oint)$ & IL-2/sIL-2R $\alpha$ ratio $>0 \cdot 2$ & 0
\end{tabular}

${ }^{\star}$ Number (\%) with past infection with one of the following sexually transmitted disease (STD) agents: $N$ gonorrhoeae, $C$ trachomatis, herpes simplex virus or $T$ vaginalis.

+ Number (\%) following exclusion of six cases that were lost to follow up (47 IFN- $\alpha$ and 47 placebo treated cases).

$\ddagger$ Number $(\%)$ with detectable levels of cytokines in the serum. Cytokine status was available from 92 cases (45 IFN- $\alpha$ and 47 placebo treated cases).

§Soluble IL2 receptor $\alpha$.
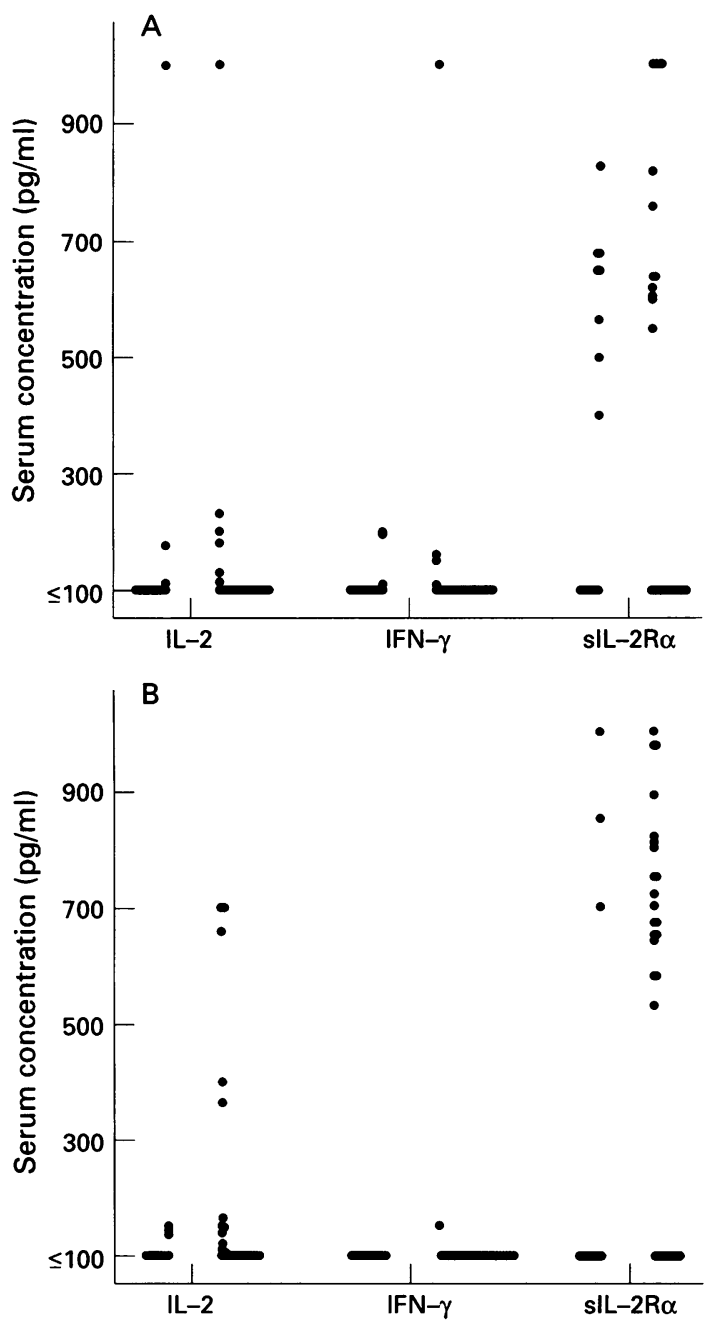

Distribution of serum levels of interleukin 2 (IL-2), interferon $\gamma($ IFN- $\gamma)$, and soluble receptor $\alpha$ for interleukin 2 (sIL-2 $\alpha$ ) in 92 women treated for genital HPV infection with systemic interferon $\alpha 2 b(A)$ or placebo $(B)$. Patients with complete or partial response (right), and no response (left) are marked individually (O). to follow up. The cytokine levels was almost identical in the two groups (table 1, fig) with the exception of IFN- $\gamma$, which was detected in only one patient (placebo group).

First, the presence or absence of specific cytokines was studied as predictors of complete response to treatment of genital HPV infection. The presence of IL-2 in the pretreatment sera seemed to predict complete response both in the IFN- $\alpha$ and placebo groups, but the ORs did not reach statistical significance $(\mathrm{OR}=0 \cdot 7,90 \% \mathrm{CI} 0 \cdot 2-3 \cdot 1$; OR $=0 \cdot 5,90 \% \mathrm{CI} 0 \cdot 1-4 \cdot 3$, table 2 ). When a high IL-2/sIL-2 $\alpha$ ratio was considered, even lower
ORs were found both for the IFN- $\alpha$ and the placebo groups $(\mathrm{OR}=0 \cdot 4,90 \%$ CI $0 \cdot 1-2 \cdot 3$; OR $=0 \cdot 3,90 \%$ CI $0 \cdot 0-1 \cdot 8$, respectively).

We then divided both the IFN- $\alpha$ group and the placebo group into two subgroups according to the presence or absence of HPV DNA as determined by the dot blot assay (high/low viral load). The predictors of complete response remained the same in patients with of high load of HPV DNA (table 3). Thus, for $\tilde{\circ}$ the final analyses the two treatment groups $\mathrm{c}$ were combined. Patients with high IL-2/sIL- 웅

Table 2 Risk of recurrences ${ }^{*}$ in relation to selected immunological risk factors

\begin{tabular}{|c|c|c|c|c|c|c|c|}
\hline \multirow[b]{4}{*}{ Risk factor } & & \multicolumn{6}{|c|}{ Treatment } \\
\hline & & \multicolumn{3}{|c|}{$I F N-\alpha$} & \multicolumn{3}{|c|}{ Placebo } \\
\hline & & \multicolumn{3}{|c|}{ Relapse } & \multicolumn{3}{|c|}{ Relapse } \\
\hline & & + & - & $O R^{*}(95 \% C I)$ & + & - & $O R^{*}(90 \% C I)$ \\
\hline Interferon $\gamma$ & + & $\begin{array}{r}3 \\
13\end{array}$ & $\begin{array}{r}4 \\
22\end{array}$ & $1 \cdot 3(0 \cdot 2-3 \cdot 1)$ & $\begin{array}{r}0 \\
13\end{array}$ & $\begin{array}{r}1 \\
30\end{array}$ & NA \\
\hline Interleukin 2 (IL-2) & + & $\begin{array}{r}13 \\
2 \\
14\end{array}$ & $\begin{array}{r}22 \\
5 \\
21\end{array}$ & $0 \cdot 7(0 \cdot 2-3 \cdot 1)$ & $\begin{array}{r}13 \\
2 \\
11\end{array}$ & $\begin{array}{r}30 \\
8 \\
23\end{array}$ & $0.5(0 \cdot 1-4 \cdot 3)$ \\
\hline IL-2 receptor (sIL-2R $\alpha$ ) & + & $\begin{array}{r}14 \\
8 \\
8\end{array}$ & $\begin{array}{l}21 \\
12 \\
14\end{array}$ & $1 \cdot 2(0 \cdot 3-2 \cdot 4)$ & $\begin{array}{r}11 \\
5 \\
8\end{array}$ & $\begin{array}{l}23 \\
19 \\
12\end{array}$ & $0.4(0 \cdot 1-1 \cdot 2)$ \\
\hline IL-2/sIL-2R $\alpha$ & + & $\begin{array}{r}1 \\
15\end{array}$ & $\begin{array}{r}14 \\
4 \\
22\end{array}$ & $0 \cdot 4(0 \cdot 1-2 \cdot 5)$ & $\begin{array}{r}8 \\
1 \\
12\end{array}$ & $\begin{array}{r}7 \\
24\end{array}$ & $0.3(0.0-1 \cdot 8)$ \\
\hline
\end{tabular}

* Odds ratios with $90 \%$ confidence intervals $(\mathrm{CI})$ were calculated according to Kelsey et al ${ }^{17}$ using those negative for the risk factor as the reference group. 
Table 3 Risk of recurrences * among HPV DNA positive patients in relation to selected immunlogical risk factors

\begin{tabular}{|c|c|c|c|c|c|c|c|}
\hline \multirow[b]{4}{*}{ Risk factor } & & \multicolumn{6}{|c|}{ Treatment } \\
\hline & & \multicolumn{3}{|c|}{$I F N \alpha(H P V D N A+)$} & \multicolumn{3}{|c|}{ Placebo (HPV DNA+) } \\
\hline & & \multicolumn{3}{|c|}{ Relapse } & \multicolumn{3}{|c|}{ Relapse } \\
\hline & & + & - & $O R^{\star}(95 \% C I)$ & + & - & $O R^{\star}(90 \% C I)$ \\
\hline Interferon $\gamma$ & + & 2 & 2 & $0.9(0 \cdot 1-5 \cdot 5)$ & $\begin{array}{l}0 \\
9\end{array}$ & $\begin{array}{r}1 \\
14\end{array}$ & NA \\
\hline Interleukin 2 (IL-2) & + & 1 & 3 & $0 \cdot 2(0 \cdot 1-1 \cdot 6)$ & 0 & $\begin{array}{r}14 \\
3\end{array}$ & NA \\
\hline IL-2 receptor (sIL-2R $\alpha)$ & $\begin{array}{l}- \\
+\end{array}$ & $\begin{array}{r}10 \\
3\end{array}$ & $\begin{array}{l}7 \\
5\end{array}$ & $0.4(0 \cdot 1-2 \cdot 7)$ & $\begin{array}{l}9 \\
3\end{array}$ & $\begin{array}{l}12 \\
10\end{array}$ & $0 \cdot 3(0 \cdot 1-3 \cdot 1)$ \\
\hline IL-2/sIL-2R $\alpha$ & $\dot{+}$ & $\begin{array}{r}8 \\
0 \\
11\end{array}$ & $\begin{array}{l}5 \\
3 \\
7\end{array}$ & $\mathrm{NA}$ & $\begin{array}{l}6 \\
0 \\
9\end{array}$ & $\begin{array}{r}5 \\
2 \\
13\end{array}$ & $\mathrm{NA}$ \\
\hline
\end{tabular}

${ }^{\star}$ Odds ratios with $90 \%$ confidence intervals (CI) were calculated according to Kelsey $e t$ al ${ }^{17}$ using those negative for the risk factor as the reference group.

$2 \mathrm{R} \alpha$ ratio tended to have a decreased risk of recurrence (two recurrences among 29 positives and 11 recurrences among 57 negatives; $\mathrm{OR}=0 \cdot 3,90 \% \mathrm{CI} 0 \cdot 1-1 \cdot 1)$. In patients with high load of HPV DNA IL-2 was associated with a decreased risk of recurrence (OR $=$ $0 \cdot 2,90 \% \mathrm{CI} 0 \cdot 0-1 \cdot 0)$. This was the case also for patients with HPV16/18 DNA (one recurrence among three IL-2 positives versus five recurrences among seven IL- 2 negatives (OR $=0 \cdot 2,90 \%$ CI $0 \cdot 0-2 \cdot 1)$. There were no recurrences in women with high loads of HPV DNA and high IL-2/sIL- $2 \alpha$ ratio, but the point estimate could not be calculated because of small numbers.

\section{Discussion}

We found that pretreatment serum IL-2 status seemed to predict the outcome of laser ablation of genital HPV lesions regardless of adjuvant interferon $\alpha 2 b$. In addition, the IL-2/sIL-2 $\alpha$ ratio had similar borderline significance as a predictor of clinical recurrences. These findings are in line with recent reports showing a positive correlation between IL-2 response and the severity of cervical HPV lesions, ${ }^{12} 13$ but a negative correlation between sIL- $2 \alpha$ status and the severity of the lesions. ${ }^{13}$ IL-2 exerts its effects via a cell surface receptor comprising three proteins, IL-2R $\alpha$, IL-2R $\beta$, and IL-2R $\gamma \cdot{ }^{18}$ Although the affinity of IL-2 to the fully maturated complex is 1000 times higher than to the IL-2R $\alpha$ alone, it is possible that the function of sIL-2 $\alpha$ is to neutralise IL-2 activity. ${ }^{18}{ }^{19}$ It would also explain why high IL$2 /$ sIL-2 $\alpha$ ratio predicted low recurrence rates.

Low dose combination therapy with IFN- $\alpha$ and IL-2 has shown additive or synergistic effects in immune surveillance prone tumours-that is, renal cell carcinoma and melanoma. ${ }^{8-10}$ Adjuvant IFN- $\alpha$ is effective in patients with HPV16/18 positive lesions ${ }^{5}$ or with $\mathrm{T}$ cell driven antibody response to an HPV16 E2 protein. ${ }^{20}$ Thus, it was plausible that in our patients, with detectable levels of IL-2 expression, HPV lesions would have regressed more readily following adjuvant IFN- $\alpha$ than placebo. This, however, did not seem to be the case, although IL-2 expression was associated with an overall beneficial effect. Other combinations, such as IFN- $\alpha$ and IFN- $\gamma$, or IFN- $\alpha$ and retinoids for the treatment of refractory warts have been suggested. ${ }^{2122}$
Owing to the small numbers we were not able to confim or refute this. Studies on new combinations of biological response modifiers in the treatment of genital HPV lesions are needed.

1 Strander $\mathrm{H}$, Cantell $\mathrm{K}$. Studies on antiviral and antitumour effects of human leukocyte interferon in vitro and in vivo. In: Waymouth $\mathrm{C}$, ed. The production and the use of interferon for the treatment and prevention of human virus infections. Rockville: Tissue Culture Association, 1974:49-56.

2 Healy GB, Geiber RD, Trowbridge AL, Grundfast KM, Ruben RJ, Price KN. Treatment of recurrent respiratory papillomatosis with leukocyte interferon: results from a papillomatosis with leukocyte interferon: results from a multice 7 .

3 Leventhal BG, Kashima HK, Mounts P and the Papilloma Study Group. Long term response to treatment with lymphoblastoid interferon alfa. $N$ Engl $\mathcal{F}$ Med 1991;325: 613-7.

4 Cirelli R, Tyring SK. Interferons in human papillomavirus infections. Antiviral Res 1994;24:191-204

5 Nieminen P, Aho M, Lehtinen M, Vesterinen E, Vaheri A, Paavonen J.Treatment of genital HPV infection with carbon dioxide laser and systemic interferon alfa2b. Sex Transm Dis 1994;24:65-9.

6 Benedetti-Panici P, Scambia G, Baiocchi G, Perrone L, Pintus C, Mancuso S. Randomized clinical trial comparing systemic interferon with diathermocoagulation in primary multiple and widespread anogenital condyloma. mary multiple and widespread

7 Condylomata International Collaborative Study Group. Randomized placebo controlled double-blind combined trial with laser surgery and systemic IFN-alpha2a in the treatment of anogenital condylomata acuminatum. $\mathcal{f}$ Infect Dis 1993;167:824-9.

8 Kedar E, Klein E. Cancer immunotherapy: are the results discouraging? Can they be improved? Adv Cancer Res 1992;59:245-322.

9 Rosenberg SA, Longo DL, Lotze MT. In: DeVita V Jr, Hellman S, Rosenberg SA, eds. Cancer: principles and practice of oncology. 3rd ed. Philadelphia: Lippincott, practice of oncolo.

10 Atzpodien J, Körfer A, Franks CR, Poliwoda H, Kirchner H. Home therapy with recombinant interleukin 2 and interferon alfa $2 \mathrm{~b}$ in advanced human malignancies. Lancet 1990;335:1509-12.

11 Simpson MA, Young-Fadok TM, Madras PN, Freeman PB, Dempsey RA, Shaffer D, et al. Sequential interleukin 2 and interleukin 2 receptor levels distinguish rejection from cyclosporine toxicity in liver allograft recipients. Arch Surg 1991;126:717-20.

12 Clerici M, Merola M, Ferrario E, Trabattoni D, Villa ML, Stefanon B, et al. Cytokine production patterns in cervical intraepithelial neoplasia: association with human papillomavirus infection. $\mathcal{F}$ Natl Cancer Inst 1997;89:245-50.

13 Hildesheim A, Tsukui T, Schiffmann MH, Swanson CA Lawler P, Rush BB, et al. T cell response to HPV and cervical neoplasia: Results for a cross-sectional study of IL-2 production and sIL-2R levels among 196 women with and without SIL. Abstract 175, 14th Int Papillomavirus Workshop, Quebec 1995.

14 Nieminen $P$, Soares VR, Aho M, Vesterinen E, Savia E, Vaheri A, et al. Cervical HPV DNA and cytology in gynecological outpatients. Am f Obstet Gynecol 1991;164: 1265-69.

15 Ferenczy A, Bergeron C, Richart R. Human papillomavirus DNA in fomites on objects used for the management of patients with genital human papilloma virus infection. Obstet Gynecol 1989;74:950-9.

16 Baken LA, Koutsky LA, Kuypers J, Kosorok MR, Lee SK, Kiviat NB, et al. Genital human papillomavirus infection among male and female sex partners: prevalence and among male and female sex partners: prevalence and

17 Kelsey JL,Thompson WD, Evans A. Methods in observational epidemiology. New York: Oxford University Press,
1986 . 
18 Waldmann TA. The IL-2/IL-2 receptor system: a target for rational immune intervention. Immunol Today 1993;14: 264-70.

19 Smith KA. Lowest doses interleukin-2 immunotherapy. Blood 1993;81:1414-23.

20 Stellato G, Pavonen J, Nieminen P, Hibma M, Vilje P, Lehtinen $M$. Diagnostic phase antibody response to the human papillomavirus type $16 \mathrm{E} 2$ protein is associated with succesful treatment of genital HPV lesions with sys- temic interferon alpha-2b. Clin Diagn Virol 1997;7:167-72. 21 Kirby PK, Kiviat N, Beckman A, Wells D, Sherwin S, Corey L. Tolerance and efficacy of recombinant human interferon $\mathrm{L}$. Tolerance and efficacy of recombinant human interferon gamma in the treatment

22 Lippman SM, Donovan DT, Frankenthaler RA, Webe RS, Earley CL, Hong WK, et al. 13-cis-retinoic acid plus interferon alpha in recurrent respiratory papillomatosis. $f$ Natl Cancer Inst 1994;86:859-61.

\section{Behçet}

\section{Historical vignette}

Behçet's syndrome is a recurrent condition which was originally described as a combination of oral and genital ulcers and various types of ocular inflammation. Several occasional features were added subsequently, including skin rashes, arthritis, thrombophlebitis, and neurological manifestations. The syndrome is rare but has attracted a great deal of interest. Behçet himself is much less well known.

Hûlusi Behçet was born in Istanbul in 1889. At this time there were several military medical schools which had originally been founded for the training of army surgeons, and Behçet graduated from one of these, at Gülhane, in 1910. He was appointed as a resident in the dermatology and syphilis clinic at Gülhane Army Hospital, where he remained for four years. On the outbreak of the first world war he moved to Eskişehir Army Hospital, near Ankara, where he became assistant director and practised as a dermatologist. When the war ended in 1918 he undertook postgraduate training, first in Budapest and then at the Charite Hospital in Berlin. On his return to Turkey he worked as a dermatologist and syphilologist at various hospitals, and in 1933 was appointed professor and clinical director of the Department of Dermatology and Syphilology at the University of Istanbul Faculty of Medicine, where he remained for the rest of his life.

Behçet was well known in Turkey and eastern Europe. In his own country he edited its only major dermatology journal for many years, and he was a regular correspondent to two weekly medical journals in Germany. He published many scientific papers on diseases of the skin, and wrote a large book on syphilis. $\mathrm{He}$ summarised his original account of the disease which now bears his name as follows:

I am presenting three patients whom I have seen respectively 21 , seven and three years ago. Each had been affected by recurrent aphthous lesions of the mouth and genitals, and by ocular inflam- mation-conjunctivitis, hypopyon, iritis and episcleritis. Our research suggests the possibility of a viral cause for this disease. Examination of the patients' teeth showed that these were in a bad state, which led us to believe that they might be a source of the infection.

These patients were first described in a Turkish journal in 1936, and again in the following year in Behçet's best known paper in the German Dermatologische Wochenschrift. At first, only a few of his colleagues accepted the syndrome as a disease entity; most thought the patients had aphthous stomatitis, erythema $\frac{\text { O }}{2}$ multiforme, Reiter's or Steven-Johnson syndromes. I But later, other cases were reported and it was realised that Behçet had been right in describing this as a new disease entity; in due course other components were identified. Its cause remains unknown to this day. $N$ Behçet himself had suggested a viral aetiology, and $N$ in recent times it has been proposed that herpes simplex virus may be involved in some way, perhaps by inducing a deficit in immunoregulation, but this is uncertain.

Behçet seems to have been a rather sad and lonely person. His mother died when he was a child, and he had few close friends. His health was indifferent, and he was a heavy smoker. He spoke good French and German, enjoyed literature and art and read a lot. $\mathrm{He} \propto$ had one child, a daughter to whom he was devoted, but his marriage ended in divorce in 1941. Thereafter, he lived and worked in his office, and in 1948 he died of a heart attack; he was 59 years old, and had been one of the best known Turkish physicians of his day. A 을 posthumous award for scientific achievement was given in 1975, and in 1980 his portrait appeared on some Turkish postage stamps. But his lasting fame lies in the disease he described and in the massive literature which it still attracts.

J D ORIEL 